\title{
Bailes boleros y flamencos en los primeros cortometrajes mudos. Narrativas y arquetipos sobre "lo español" en los albores del siglo XX
}

\author{
Boleros and Flamenco Dancing in the Early Silent Films. \\ Narratives and Archetypes of Spanishness \\ in the Early Twentieth Century
}

\author{
Cristina Cruces-Roldán \\ Grupo de Investigación GEISA, Universidad de Sevilla \\ ccruces@us.es
}

\section{RESUMEN}

El artículo localiza y cataloga 37 filmaciones del periodo 1894-1910 que conforman un corpus de cine primitivo sobre bailes españoles, boleros y flamencos. Estas películas mudas fueron registradas en exposiciones universales o como resultado de dramatizaciones teatrales, parodias e historias de ficción y están contenidas en los archivos The Library of Congress, Gaumont-Pathé, las colecciones Pathé y Frères Lumière y los Huntley Films Archive. El análisis de contenido de estos archivos demuestra las potencialidades de la filmografía pionera como fuente documental para conocer los procesos de construcción y reproducción de los clichés nacionales.

Se expone la coexistencia de dos narrativas en estos registros pioneros: la testimonial del baile como expresión artística, y el discurso identitario sobre "lo español" a través de las disposiciones corporales y los elementos ambientales de los fotogramas. El modo de representación del arquetipo hispánico confirma que el cine de los inicios fue una vía de transmisión continuista respecto a los imaginarios estéticos, psicológicos y morales insertos en la espagnolade, para los cuales etnicidad y género funcionaron como sustratos convertidos en cliché de una cultura periférica y, a la vez, fascinante.

Palabras clave: Cine; Estereotipos; Baile español; Flamenco; Género; Gitanos.

\section{SUMMARY}

The article locates and catalogues a corpus of 37 early cinema recordings (1894-1910) containing Spanish bolero and flamenco dances. These silent movies were recorded at universal exhibitions, or as a result of theatrical dramatizations, parodies and fiction stories, and are now in the archives of the Library of Congress, Gaumont-Pathé, Pathé and Frères Lumière collections and the Huntley Films Archive. An analysis of the contents of these archives demonstrate the potential of pioneering filmography as a documentary source for the construction and reproduction of national clichés.

We consider two coexisting narratives in these early records: testimonial to dance as artistic expression and the identity discourse of "Spanishness" through the bodily disposition and environmental elements of the frames. The representation of the Hispanic archetype shows that early cinema was a continuist route of transmission of the aesthetic, psychological and moral images 
of the "espagnolade, for which ethnicity and gender operated as substrata that became clichés in a peripheral and fascinating Spanish culture.

Key words: Cinema; Stereotypes; Spanish Dances; Flamenco; Gender Gypsies.

En su Viaje por España (1840), y tras asistir a una función de teatro, Téophile Gautier afirmaba desconsolado a su paso por Vitoria: "Está demostrado que los bailes españoles existen solo en París, del mismo modo que las caracolas se encuentran siempre en los comercios y nunca a orillas del mar." (2006: 38). Tan esencial como el lamento de nuestro crítico — siempre entusiasta de las danzas del país, con las que tendría mejor suerte al sur de la Península- sus palabras destilan una certeza: que la capital francesa estaba ya por estas décadas escénicamente inoculada de "lo español" desde que, unos años antes, el bolero nacional sentara plaza en los teatros parisinos. Tal era la fama de los bailes españoles que cuando, a finales del siglo XIX, el cine se instala entre las nuevas ofertas de ocio urbanas y abre la etapa conocida como de "cine primitivo" o "de los inicios", algunas de las primeras filmaciones escogieron estas danzas junto a misceláneos números de cómicos, forzudos, bailarines, magos, saltimbanquis, gimnastas y artistas de cualquier condición, combinando la fidelidad descriptiva del espectáculo con lo que Gunning ha denominado el "cine de atracciones" (1986: 64) 1 .

La temprana devoción por el baile español irradió también hacia la pionera cinematografía norteamericana. En 1894, la Edison Manufacturing Company grabó a la bailarina almeriense Carmencita, primera impresión histórica de una mujer en movimiento (Musser 1997: 34; Mora 2011, 2014). Desde entonces hasta la década de 1910, cuando se produce el paso al "sistema de integración narrativa" y lo que se ha venido en sintetizar como la "invención del cineasta" (Gunning y Gaudreault 1989: 59; Jost 1996), una colección de películas con bailes españoles, flamencos y boleros de raigambre popular y proyección escénica convivieron en el celuloide con otras danzas individuales y de conjunto. Unas filmaciones en general poco conocidas, de las que apenas se conservan unas decenas, pero que constituyen una fuente de investigación muy relevante al datar y describir los bailes territoriales y los intérpretes de la época, cumpliendo así una primera función testimonial: la de "registrar fenómenos visibles con una gran fidelidad" (Nichols 2001: 74).

Sin embargo, hay que contemplar el cine no solo como "documento procedente del pasado, sino también (respecto) al papel que haya tenido como agente histórico, contribuyendo a la configuración de la realidad del momento" (Amador 1996: 116). La idea de "representación" atiende justamente a las estructuras subyacentes a estos documentos y a su sistema de producción de significados, a la relación siempre interpretativa entre el texto audiovisual y la realidad a partir de la cual éste se fija (Rigney 2007: 415). En nuestro caso, el cine primitivo fue un medio masivo, de amplia difusión, a través

\footnotetext{
${ }^{1}$ Para una profunda crítica a la búsqueda de eras y puntos de ruptura en el "cine de los inicios" y a la atribución de orígenes al séptimo arte, con nuevas clasificaciones de géneros, épocas y autores, consultar Gunning y Gaudreault (1989). El debate terminológico sobre la categoría "cine primitivo" es agudamente expuesto por Gaudreault (2006).
} 
del que se reflejaron imaginarios identitarios, festivos y estéticos dominantes acerca de la cultura española. Son estos los que pretendemos desvelar.

Nuestro primer objetivo ha sido localizar, clasificar, describir y analizar el corpus de películas que contienen bailes españoles para el primitivo periodo 1894-1910. Filmaciones que, en todos los casos, fueron de factura foránea, ejemplificaron una atrayente encarnación de patria y moral ajena al decurso industrial del resto de Europa, y ayudaron a construir un discurso icónico esencializador acerca del país y sus tipos populares. Proponemos situar a la narrativa fílmica de los inicios junto a otras representaciones jerarquizadoras que soportaron "lo nacional" en el arte, los monumentos históricos y la desmedida atracción popular por la música y los bailes². Ocuparon así un espacio de continuidad respecto a producciones literarias y plásticas arrastradas desde el siglo XVIII, que venían simplificando, desatendiendo o directamente despreciando y anulando los relatos polifónicos posibles sobre el país, la heterogeneidad de sus tradiciones y formas identitarias.

El ejemplo más conocido de este cliché es la internacionalización del mito de Carmen, que tanto éxito había cosechado en las versiones literaria de Prosper Mérimée (1845) y operística de Bizet (estrenada en 1875), y en el que intersecan género, etnicidad y clase como categorías estructurantes de "lo español". Mujeres que bailan, gitanos toscos y arrogantes tipos del común se personificaban en una figura que —además de la dimensión orientalizante estudiada por Colmeiro (2003) — suponía también el "prototipo de una nueva clase, un proletariado femenino con una enorme carga de rebeldía, formado por mujeres independientes en lo económico y sentimentalmente activas" (Vera y Meléndez 2008: 345). El mito de Carmen culminaría en una amplísima producción literaria, artística y también cinematográfica que, solo entre 1909 y 1933, daría lugar a dos decenas de películas de ficción. La mundanidad y el descaro femeninos, como también su paralelo empoderamiento y capacidad de seducción, resultaban una combinación explosiva que, una vez superadas las visiones moralizantes del siglo precedente, los viajeros románticos definieron como característica de España y singularmente de Andalucía.

Este papel trascendería al género musical flamenco, que se encontraba desde 185060 en proceso de codificación a partir de los sustratos folclórico, popular, teatral y bolero de músicas y danzas que habían sido el delirio de proscenios, academias y salones. Sobre ellos se dispuso una reformulación de robusta estética agitanada, que daría lugar a un nuevo género artístico prontamente estigmatizado como suburbial e innoble, pero inscrito en la romántica reacción nacional contra el afrancesamiento de las costumbres y el apogeo de la ópera italiana (Lavaur 1976; Steingress 1993) 3 $^{\text {No }}$

\footnotetext{
${ }^{2}$ Se ha cuantificado en un doce por ciento la producción de escenas costumbristas rodada en España durante esta etapa (danzas, festejos, corridas de toros...), y en un 21,6 las vistas y panorámicas paisajísticas (González 2005: 14). Para la creación de la imagen internacional del mito español y sus asociaciones hiperbólicas y maniqueas en arte, literatura y prensa, consultar Calvo Serraller (1995).

${ }^{3}$ El afrancesamiento no se limitó al Siglo de las Luces, sino que perduró a lo largo del siglo XIX. El viajero Slidell Mackenzie, por ejemplo, se lamentaba de que, entre sus dos viajes a España (1827 y 1834) se hubieran pervertido la cachucha y el bolero con una agilidad y unas "alas de paloma" más propias de las formas francesas. Su contemporáneo Richard Ford consideraba ridícula la insistencia de las clases altas por emular el ballet francés en sus salones.
} 
fue caso único en la producción musical decimonónica: también la música "culta" interesada por la tradición jugaría un papel identificador de la cultura española pocos años después, esta vez en Europa. El andalucismo y exotismo que durante el siglo XIX venían revirtiendo en España en una empresa de construcción nacional (Alonso 2010: 83-104) se insertarían a principios del XX en complejas redes transnacionales de intereses y preferencias geopolíticas ${ }^{4}$.

Como las categorías de "arquetipo" e incluso "carácter nacional", el concepto "estereotipo" es una herramienta analítica muy útil para adentrarnos en el modelo de representación cinematográfica de nuestra investigación. Seguimos aquí a Beller y Leerssen (2007) al considerar los estereotipos como proyecciones políticas e intelectuales, más que filosóficas u ontológicas: son "explicaciones" antes que cuestiones que han de ser explicadas (Leerssen 2007: 19). En este sentido, el cine finisecular se sitúa en los albores de la "españolada", un concepto acuñado desde el romanticismo francés (espagnolade) que Camporesi (1997) ha sabido defender por su valor teórico e historiográfico como un conjunto de tradiciones exóticas y folklóricas que, falseadas por exageración o limitación, aparece como referente extranjero en temas e imágenes.

La literatura de viajes y las artes plásticas ya habían participado de este imaginario construido "con esa forma de exotismo benevolente que solicita condescendencia", gracias al cual «el declive de España y su ocupación por la Francia napoleónica hicieron posible la emergencia de una imagen idealizada: la España de las castañuelas, las corridas de toros, las noches templadas, y las pasiones pintorescas" (Leerssen 2012: 64-68). Poco hallaremos en ellas del germen del debate regeneracionista que se estaba produciendo en España, declarado enemigo del pintoresquismo y el flamenquismo. Las modificaciones habidas en los últimos años del siglo XIX en los campos del entretenimiento y los medios de comunicación (el cine, entre ellos) funcionaron como catalizador final para la plasmación de estos estereotipos durante la centuria siguiente (Benet y Sánchez-Biosca 2013: 561).

No obstante, conviene recordar que la españolada no fue solamente una esencialización construida desde la alteridad: también los intelectuales españoles jugaron un papel en la difícil negociación entre los clichés popularizados y la gestación de ese mismo regeneracionismo. Por un lado, el casticismo y el costumbrismo nacionales originaron una amplísima producción artística, pictórica, fotográfica y escénica, y los nacientes (aunque prontamente abortados) estudios folclóricos españoles se acogieron al imaginario popular ${ }^{5}$. Romanticismo y realismo vinieron a sustituir el viejo arquetipo de la España imperial connotado de crueldad, iglesia y genocidio, por los tipos populares y las "naturales" tendencias al baile y el cante que funcionaron como referentes de "lo español" a partir de la metonimia meridional. Pero, por otra parte, el arraigo del prejuicio gestado fuera de España también convivió con la «visión negativa de lo propio" - la superstición, la intolerancia, el atraso- en la construcción con-

\footnotetext{
${ }^{4}$ Samuel Llano, por ejemplo, ha indagado cómo la búsqueda de una posición política hegemónica de Francia frente a Alemania en las primeras décadas del siglo XX tendría lugar "by claiming cultural proximity to their "exotic" neighbours, while simultaneously seeking to establish a hierarchical distance and cultural prophylaxis" (Llano 2013: XVII).

${ }^{5}$ En el caso andaluz, con sede principal en Sevilla, inicia la andadura Antonio Machado y Álvarez Demófilo, que publicó su pionera Colección de Cantes Flamencos en 1881.
} 
temporánea de una identidad común (Andreu 2009: 41). Un proceso iniciado en el siglo XVI que ensalzaba lo popular pero lo reducía a un sustrato ajeno a las artes oficiales (Navarrete 2009), obligando a los pensadores a debatirse entre una reflexión intelectualizada sobre la nación, y la negociación sobre aquellos estereotipos que ellos mismos reconocían.

En suma, lejos de existir una sola interpretación sobre la identidad nacional, confluyeron en el periodo desde entusiasmos patrióticos, hasta luchas entre conservadores y reformistas y refuerzos identitarios de tono cultural en una "Historia de las dos Españas" que, antes que dualista, Santos Juliá (2004) ha demostrado intrincada y coral. La debilidad del Estado frente a una consolidada imagen exterior, la fuerza de la Iglesia, la polaridad de clases y la "traición de la burguesía" contribuyeron, entre otros factores, a que el siglo XIX entregara una identidad problemática al siglo por venir, donde tomaron posiciones diversos agentes y proyectos heterogéneos que pugnaban por hacerse hegemónicos (Álvarez Junco 2003).

\section{HACIA UN CORPUS DE PELÍCULAS SOBRE BAILES ESPAÑOLES}

En este contexto de conflicto por la hegemonía interpretativa y de debate finisecular sobre las relaciones entre identidad, nación y música, hacen su aparición nuestros cortometrajes que, como veremos, se mantuvieron ajenos a tales tensiones. Se trata de un patrimonio material disperso, escasamente conservado y estructurado en catálogos históricos durante décadas, cuyo rastreo es todavía hoy un proceso abierto de tenaces pesquisas, seguros descartes y eventuales hallazgos ${ }^{6}$. Afortunadamente, algunas instituciones facilitan en la actualidad su libre disposición online. Entre ellas, hemos seleccionado los archivos históricos de The Library of Congress (Washington D.C., EEUU, en adelante TLC) y el Centre National de la Cinématographie francés (CNC), de carácter público, y los archivos privados Gaumont-Pathé (Saint Ouen, Francia, GPA), las colecciones Pathé y Frères Lumière y los Huntley Films Archive (HFA) ${ }^{7}$. La búsqueda y el visionado de contenidos seleccionados a través de etiquetas temáticas nos han permitido catalogar 37 referencias con bailes españoles boleros o flamencos de entre 1894 y 1910 que permiten el visionado directo (Tabla 1). A ellos se suman otros archivos recogidos en catálogos o estudios, que no son accesibles o están posiblemente desaparecidos ${ }^{8}$.

\footnotetext{
${ }^{6}$ El Tercer Informe sobre la aplicación de la Recomendación sobre el patrimonio cinematográfico de la Comisión Europea reconocía en 2012 un desolador panorama de un millón de horas sin digitalizar en archivos europeos y denunciaba la conservación solo del diez por ciento de este patrimonio. Para un análisis de las posibilidades de acceso al cine mudo a través de Internet, consultar Barrientos (2013).

${ }^{7}$ Accesos web de citación principales: <www.loc.gov $>$, <http://www.gaumontpathearchives.com>, $<$ http://www.cnc.fr $>$ y $<$ http://www.huntleyarchives.com/ $>$. En algún caso, los datos nos han redirigido a otros portales más fragmentarios, a la búsqueda de algún visionado concreto. Magnos archivos como la Filmoteca Española no permiten acceder a todas las colecciones. Aunque destaca la Colección Sagarmínaga para este periodo, lamentablemente no incluye ningún registro para nuestros objetivos.

${ }^{8}$ En total, dieciocho títulos. En 1894, "Carmencita", otra toma de la anterior, localizada en el National Fairground Archive de la Universidad de Sheffield y referenciada en Mora (2014). En Aubert y Seguin (1995) se citan tres películas más del periodo: "Ballet Espagnol» (1902), "Hermoso
} 
Desde un punto de vista técnico, la cinematografía del periodo 1894-1910 busca una equivalencia realista, jugando a la vez con la seducción icónica y las limitadas posibilidades técnicas y de longitud de los rollos. Salvo en la ficción, secuencias y escenas de bailes son idénticas a la duración de los números, que responden a su función testimonial: la unidad de sentido de estos registros deviene de la captación fija de un hecho, un acto que sucede en la realidad, aunque sea la del escenario. En su contenido, sin embargo, se verifican dos niveles del discurso fílmico: el estrictamente dancístico, y las lecturas en torno a la construcción social e histórica de la danza como parte de la identidad nacional.

La amplitud de contenidos de estos testimonios, que ocupan desde las pruebas técnicas experimentales hasta las primeras películas de ficción, es más que notable. Exigen así la multiplicación de variables metodológicas y enriquecen su potencialidad analítica: aparecen figuras reconocidas del arte escénico y personajes anónimos, gitanos y no gitanos, profesionales o no; los figurantes se nos muestran individualizados, en forma de cuadro coreográfico o pequeños grupos de actores; el fondo sobre el que se plasman las acciones pueden ser el estudio, escenarios teatrales, entornos monumentales, naturales o callejeros... El inventario incluye una amplia gama de registros, como el singular experimento Andalusian Dance que registró en Sevilla el británico Henry William Short con filoscopio en 1896, los cuadros flamencos de la casa Lumière de 1898 con figurantes y tipos castizos puestos al servicio de la exaltación nacional que aún olía a viajero norteuropeo, un repertorio de danzas para GaumontPathé protagonizadas solo por mujeres, identificadas o no, películas de ficción, y las series de Alice Guy en Sevilla sobre los boleros de Sevilla y los bailes gitanos de Granada de 1905 [Imagen 1].

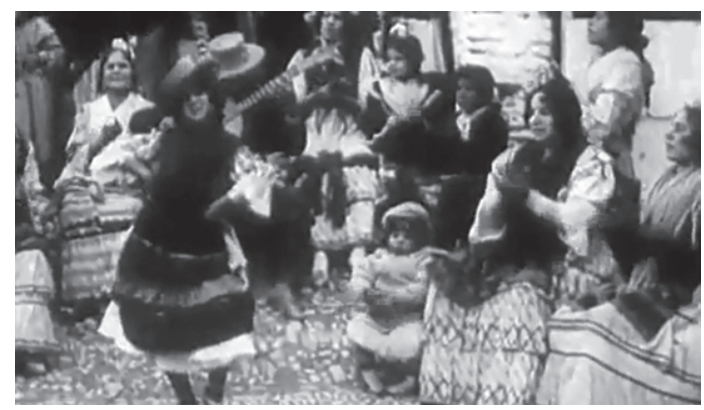

Imagen 1.-Espagne: Granada. Danses gitanes. Sévillane, 1905. Original Gaumont-Pathé. Fotografía recuperada de [Video] <https://www.youtube.com/watch?v=u19uY-iN6L4> para objetivos de investigación (excepción legal de cita, DP).

baile español de manolas y toreros" (1902) y "Baile por la Bella Romero, La Jota bailado [sic] por la Bella Romero y parodia del torero" (1903). La primera de ellas bien pudiera ser la del mismo título contenida en el CNC francés, pues también se trata de una escena interpretada por el Ballet de la Ópera de París. Los GPA incluyen los títulos no accesibles con escenas de baile español "Danses Andalouses" (1907), "Une nuit parisiense" (1909) y "El Barbero de Sevilla" (1910). Davis y Powrie incluyen diez películas sobre Carmen, algunas de las cuales debieron contener bailes, entre 1906 y 1910. Siete de ellas no están localizadas. Los HFA incluyen asimismo la película "Music Hall Stars" (datada en torno a 1910 pero no visionable), en la que aparece un baile flamenco femenino. 
TABla 1.-Películas con bailes flamencos y BOleros, 1894-1910

(SOLO LAS QUE PERMITEN EL VISIONADO)

\begin{tabular}{|c|c|c|}
\hline 1894 & 1 & $\begin{array}{l}\text { Carmencita. Edison Manufacturing Company, The Library of Congress. } 21 \text { se- } \\
\text { gundos. Intérprete: Carmen Dauset "Carmencita". Producción: W.K. Dickson, L. } \\
\text { William Kennedy-Laurie. Cámara: William Heise. Filmada en Estudios Black Maria, } \\
\text { West Orange, New Jersey. }\end{array}$ \\
\hline \multirow[t]{2}{*}{1896} & 2 & $\begin{array}{l}\text { Andalusian Dance. Paul's Animatograph Works. 26s. Intérpretes desconocidas. } \\
\text { Operador: Henry William Short. Filoscopio. Filmada en Sevilla. }\end{array}$ \\
\hline & 3 & $\begin{array}{l}\text { Danse espagnole par la Belle Otero. Pathé. Gaumont-Pathé Archives. 42s. Se } \\
\text { identifica la intérprete erróneamente con La Bella Otero. Filmada en París. }\end{array}$ \\
\hline \multirow[t]{2}{*}{1898} & $4-15$ & $\begin{array}{l}\text { Danses espagnoles (doce películas: El Vito, Estrella de Andalucia, La Jota, Bo- } \\
\text { leras robadas-ensemble, Bolero de medio paso, Las peteneras, Las manchegas, } \\
\text { Boleras robadas-deux, La malagueña y el torero, Bolero de medio paso-ensem- } \\
\text { ble, La sal de Andalucia, El ole de la Cura [sic: se correspondería con "El ole de } \\
\text { la Curra"]). Catalogue Géneral des Films Lumière. 12:28m. Operador: se atribu- } \\
\text { yen a Alexandre Promio, Francis Doublier o Jean Busseret. Filmadas en el Ce- } \\
\text { nador de la Alcoba, Alcázar, Sevilla. }\end{array}$ \\
\hline & 16 & $\begin{array}{l}\text { c. Danses espagnoles. Pathé-Personnalités. GPA. 28s. Intérprete: La Bella Ote- } \\
\text { ro. Operador: posiblemente, Félix Mesguish. ¿Filmada en San Petersburgo? }\end{array}$ \\
\hline \multirow[t]{5}{*}{1900} & 17 & $\begin{array}{l}\text { Danse espagnole de la feria cuadro flamenco. Collection Parisienne, Films } \\
\text { Lumière. 26s. Intérpretes: antes atribuido al Cuadro Flamenco del Maestro Ote- } \\
\text { ro, recientemente identificados por Mora (2016) como el Mulato Meric y otros } \\
\text { intérpretes. Exposición Universal, París. }\end{array}$ \\
\hline & 18 & $\begin{array}{l}\text { Danse espagnole de la feria Sevillanos. Collection Parisienne, Films Lumière. } \\
\text { 23s. Intérpretes: antes atribuido al Cuadro Flamenco del Maestro Otero, recien- } \\
\text { temente identificados por Mora (2016) como Negro Meric y otros intérpretes. } \\
\text { Exposición Universal, París. }\end{array}$ \\
\hline & 19 & $\begin{array}{l}\text { El Cid. Gaumont-Pathé Phono Cinéma Théâtre, GPA. 1:56m. de 2:52m. totales. } \\
\text { Intérpretes: Carlotta Zambelli y Michel Vasquez. Phono Cinéma Théâtre, París. }\end{array}$ \\
\hline & 20 & $\begin{array}{l}\text { Terpsichore. Gaumont-Pathé Phono Cinéma Théâtre, GPA. 2:19m. Intérpretes: } \\
\text { Christine Kerf y Achille Viscusi (Ballet Mme. Saharet). Coloreado manual. ¿Fil- } \\
\text { mada en París? }\end{array}$ \\
\hline & 21 & $\begin{array}{l}\text { c. Matador Romance. HFA, Film 2917. 3:26m. Intérpretes y localización de la } \\
\text { filmación desconocidos. }\end{array}$ \\
\hline 1901 & 22 & $\begin{array}{l}\text { Spanish Dancers at the Pan-American Exposition. LOC Motion Picture, TLC. } \\
\text { 1:20m. Intérpretes desconocidas. Exposición Pan-Americana, Buffalo. }\end{array}$ \\
\hline 1903 & 23 & $\begin{array}{l}\text { 1903. Danses Diverses: Tango. Fandango. Pathé Documentaire. GPA. } 23 \text { y 27s. } \\
\text { de 11:16m. totales. Intérprete desconocida. ¿Filmada en París? }\end{array}$ \\
\hline \multirow[t]{3}{*}{1905} & 24 & $\begin{array}{l}\text { Espagne. Moeurs andalouses. Série Rouge, GPA. 2:01m. de 8:57m. (total de } \\
\text { metraje). Intérpretes desconocidos. Filmada en Sevilla. }\end{array}$ \\
\hline & 25 & $\begin{array}{l}\text { Tango. Gaumont Fiction, GPA. 2:00m. Intérprete desconocida. Directora: ¿Alice } \\
\text { Guy? Coloreado manual. Filmada en Patio de la Casa de Pilatos, Sevilla. }\end{array}$ \\
\hline & 26 & $\begin{array}{l}\text { La malaguena ( } \mathrm{sic} \text { ) y el torero. Gaumont Fiction, GPA. 2:00m. Intérpretes: ¿Cua- } \\
\text { dro del Maestro Otero? Coloreado manual. Filmada en Patio de la Casa de Pilatos, } \\
\text { Sevilla. }\end{array}$ \\
\hline
\end{tabular}




\begin{tabular}{|c|c|c|}
\hline & 27 & $\begin{array}{l}\text { Espagne: Seville. Marengaro. Danse gitane [sic: se correspondería con el gra- } \\
\text { nadino "tango de los merengazos"]. Documentaire Gaumont Serie Rouge, GPA. } \\
\text { 4:19m. Intérpretes: ¿Zambra la Capitana de Granada? Directora: Alice Guy. Fil- } \\
\text { mada en Calle Jesús, Albaicín, Granada. }\end{array}$ \\
\hline & 28 & $\begin{array}{l}\text { Espagne: Granada. Danses gitanes. Sévillane. Documentaire Gaumont Serie } \\
\text { Rouge, GPA. 7:44m. Intérpretes: ¿Zambra la Capitana de Granada? Directora: Alice } \\
\text { Guy. Filmada en Calle Jesús, Albaicín, Granada. }\end{array}$ \\
\hline 1906 & 29 & $\begin{array}{l}\text { Le deserteur. Pathé Fiction, GPA. 18s. de 8:00m. totales. Realizador: Lucien } \\
\text { Nonguet. Escena: André Heuzé, 1906. ¿Filmada en Francia? }\end{array}$ \\
\hline \multirow[t]{2}{*}{1907} & 30 & $\begin{array}{l}\text { Little Tich, danse espagnole. Gaumont Primitifs, GPA. 1:30m. Intérprete: Little } \\
\text { Tich. ¿Firmada en el Folies Bergère, París? }\end{array}$ \\
\hline & 31 & $\begin{array}{l}\text { c. Little Tich, parodie de danse espagnole. s/r. 1:09m. Intérprete: Little Tich. } \\
\text { ¿Filmada en el Folies Bergère, París? }\end{array}$ \\
\hline 1908 & 32 & $\begin{array}{l}\text { Sang espagnol. Filmographie Pathé. 3:10m. Intérpretes desconocidos. ¿Filmada } \\
\text { en Francia? }\end{array}$ \\
\hline 1909 & 33 & $\begin{array}{l}\text { Clair de lune espagnol. Gaumont Primitifs, GPA. 4:00m. Directores: Étienne Arnaud } \\
\text { y Émile Cohl. Copia de original almacenado en TLC. ¿Filmada en Francia? }\end{array}$ \\
\hline \multirow[t]{4}{*}{1910} & 34 & $\begin{array}{l}\text { Danse Époque 1910. Actualité Gaumont Boites Vertes, GPA. 2:15m. Intérprete: } \\
\text { Margherite "Elgé». ¿Filmada en el Folies Bergère, París? }\end{array}$ \\
\hline & 35 & $\begin{array}{l}\text { Le charme des fleurs. Pathé Fiction, GPA. } 7: 26 \mathrm{~m} \text {. Intérprete: Stacia Napier- } \\
\text { kowska. Director: Gastón Velle. ¿Filmada en Francia? }\end{array}$ \\
\hline & 36 & $\begin{array}{l}\text { c. Danse du voile. Fantasía española. Danse espagnole. La Trianeras [sic]. } \\
\text { GPA. 6:00m. Intérprete desconocida. ¿Filmada en Francia? }\end{array}$ \\
\hline & 37 & $\begin{array}{l}\text { (anterior) Alhambra de Grenade (Espagne). Actualité Pathé (Alexandre), GPA. } \\
0: 26 \mathrm{~m} \text {. Intérpretes desconocidas. La Alhambra, Granada. }\end{array}$ \\
\hline
\end{tabular}

FUENTE: Elaboración propia a partir de las bases de datos de los archivos consultados.

Algo más de la mitad de estas películas (diecinueve) fueron rodadas en el entorno nativo de producción de las danzas, siendo Andalucía la única zona del país donde se filmaron, concretamente en Sevilla y Granada. Fuera del país, otros diecinueve filmes - catorce de ellos seguramente en París, dos con certeza en Estados Unidos- reunieron bailes y actores que, con frecuencia de forma ficta y afectada, utilizaron la estética española para sus ejecuciones. La producción, sin embargo, nunca fue española: aunque existió una cinematografía primitiva en el país, todos los filmes de bailes flamencos y boleros de este periodo descubiertos hasta el momento se filmaron por empresas extranjeras? ansiosas de contar con el favor de unos públicos que ya no eran exclusivamente los del teatro burgués, sino también los de incipientes y exitosas salas de proyección que comenzaron a intercalar filmes y placas de pizarra con actuaciones musicales.

No trataremos aquí ni las danzas exclusivamente femeninas (una estela de género de la que, en distintos rangos, participan todas estas películas), ni las escasas escenas de bailes pintorescos, boleros y gitanos que fueron filmados en Andalucía (Cruces 2015).

\footnotetext{
9 Para un acercamiento a la historia de la producción cinematográfica en España, recomendamos las progresivas aportaciones de Torres (1989), Seguin (1995) y Benet (2012).
} 
Centraremos nuestro análisis específico en los cortometrajes que recogen escenas de grupo (números 17, 18 y 22 del listado), dramatizaciones teatrales (19 y 20), cuadros de pantomima $(30,31,34)$ y películas de ficción $(21,29,32,33$ y 35) registrados fuera de España, donde el distanciamiento del foco nativo original permitió vincular de modo más nítido acciones, ambientes y figurantes con estos imaginarios sobre "lo nacional".

\section{LAS EXPOSICIONES UNIVERSALES}

Comenzamos nuestra presentación con los registros 17, 18 y 20, que se insertan en dos magnas exposiciones con que se abre el siglo XX: la Exposición Universal de París (1900) y la Exposición Panamericana de Buffalo (1901). El contexto de estas exposiciones es inmediato al de las exploraciones geográficas en los nuevos territorios del colonialismo europeo y la intención que las acompaña es la de plasmar particularidades culturales y raciales, bien con objetivos comerciales, bien con pretensiones (pseudo)científicas.

El interés por los pueblos no occidentales y las "culturas primitivas" objeto de la naciente disciplina antropológica, proporcionó en la segunda mitad del siglo XIX un repertorio humano fascinante para las tecnologías del sonido y la imagen. No es casualidad que, a la vez que se generalizaban las impresiones fonográficas de músicas populares, Edison rodara en 1894 las danzas nativas de los indios sioux del espectáculo Wild Wild West junto a Carmencita, gimnastas y artistas estilizadas; en Francia, la emulación de danzas regionales del continente y bailes orientales de tono ritual hizo furor en los teatros parisinos, y también quedaron registradas en el cine primitivo.

Las corrientes evolucionistas del momento se plasmaron en el fin de siglo en unas exposiciones que mostraban vestigios de primitivismo y tradición junto a exhibiciones de modernidad y progreso. Elementos materiales, costumbres y tipos humanos exponían la diversidad física y cultural pasada y presente desde los presupuestos del biologicismo racial: el Pabellón Etnológico de la Exposición de Buffalo, donde se enmarca una de nuestras películas, contaba con una terraza con balaustrada y estatuas que representaban "las cinco razas diferentes". Como señala Lourdes Méndez, "El moderno concepto de raza, basado en lo biológico, servirá de piedra angular para organizar y clasificar jerárquicamente la diversidad humana y cultural, según la legitimación científica y moral del papel civilizador de occidente" (2004: 73-74). La ambivalente percepción de estas culturas "inferiores" para las que "Europe's domination over the Orient was almost a fact of nature, (Said 1978: 257) se fijó en los cuerpos epidermializados y etnizados de bárbaros y salvajes, y en los cuerpos marcados de las bailarinas de corte exótico o del sur de Europa que remitían a un imaginario cultural orientalizante. No hay sino que recordar la trágica historia del pigmeo Ota Benga en la Exposición Universal de Saint Louis de 1904 y la exhibición en este mismo recinto de bailaoras flamencas como parte de una atracción sobre "las calles de Sevilla".

Aunque en el cine de los inicios estas danzas convivieron con las más estilizadas que encarnaban un modelo "civilizado" ${ }^{10}$, y también con otras que anticipaban la re-

\footnotetext{
${ }^{10}$ Como apunta Rony (1996:11), también el periodo primitivo de la historiografía cinematográfica — que coincidió con la institucionalización de la Antropología - se enlaza inextricablemente
} 
novación de formas ${ }^{11}$, para el baile español fueron privilegiados los figurantes de clase popular, género femenino y pretendida etnicidad gitana. Los tres registros catalogados de Lumière Frères y Edison Manufacturing Company en París y Buffalo recurren al cante, el rasgueo de guitarra, el baile y personajes aflamencados — sobre todo mujeres - que se presentan como iconos nacionales y gitanos. Las danzas, encarnación y envoltura de una cultura tal vez no pre-civilizada pero sí atrasada llamada España, nos introducen en la mirada periférica hacia un país que, durante la Restauración, simbolizaba el polo opuesto al progreso europeo.

\section{EL FOCO FRANCÉS: FLAMENCAS EN PARÍS, 1900}

Una vez perfeccionados y patentados sus sistemas de proyección, los hermanos Lumière inician un amplio y pionero patrimonio documental en Francia, que arranca en 1895 con la proyección de Salida de los obreros de la fábrica. Un año después nacen las primeras firmas industriales en el país galo, entre las que pronto destacaría la Casa Pathé, inicialmente competidora de Gaumont y con la que terminó por fusionarse en 1927. En Gaumont desarrolló su trabajo Alice Guy, considerada la primera cineasta de la historia y que dirigió desde 1896 una notable serie de filmaciones con tomas de campo en España, entre ellas bailes boleros y flamencos andaluces (1905).

En Francia existía una vieja devoción por la "voluptuosidad" de las bailarinas españolas, tiznada con los detalles muy emocionales de unos viajeros que, en esto, se diferenciaron del mayor pragmatismo inglés. La afamada disposición a los bailes patrios en España alternaba con la eventual presencia en famosos escenarios franceses de boleras "nativas" que ejecutaban seguidillas y fandangos, y de copistas estilizadas cuyos repertorios se inspiraban en el bolero o la cachucha. Las estampas de Félix García o las femeninas nacionales de Pepita de Oliva o "La Nena" coexistían con las evoluciones representadas por otras artistas europeas como Guy-Stéphan, Fanny Essler o La Taglioni. Como afirmaba el novelista Barbey d'Aurevilly,

¡Ser española en aquella época no era cualquier cosa! Era una señal de distinción. (...) los bailes de Mariano Camprubí y Dolores Serral hacían apreciar excesivamente a las mujeres de naranja con las mejillas de granada; y quien se enorgullecía de ser española, no siempre lo era, pero se enorgullecía de ello (Plaza 2005: 61).

Casi desde el nacimiento mismo del género flamenco, la capital francesa empezó a acoger artistas que cosechaban a la par exitosos triunfos y aceradas críticas. Están documentadas la presencia, entre otros, de Manuel Romero, la Loca Mateo, Dolores

con los discursos sobre la raza. No es el momento de desarrollar la complejidad de las relaciones entre raza, cine y etnografía, que merecerían capítulo aparte. Remitimos para la cuestión, además de Rony, a autoras como Faye Ginsburg (2002) o Allison Griffiths (2002).

${ }^{11}$ Necesario es aquí mencionar el papel de artistas como Loie Fuller, quien tras el vacío posterior al languidecimiento del ballet romántico estableció nuevos códigos corporales. Con expectativas de "alta cultura" dio pie a un contexto de vanguardia morfológica y reivindicación de la naturaleza corporal, a más de amalgamar un modelo abstracto y de apariencia desmaterializada, a cuya exhibición teatral incorporó sin embargo nuevos elementos físicos: telas articuladas (danse serpentine), luminotecnia, telones, colorido... 
la Parrala, Paco de Lucena, Lola Triana, "Mme. Gómez", y La Cuenca en espectáculos flamencos teatrales, como el que en 1889 se presentó en el Gran Teatro de la Exposición Universal de París, con gitanos granadinos y La Macarrona como artista sobresaliente y que fue cita obligada para la gente chic (Le Gaulois, 10 janvier 1880; Álvarez Molina 2006: 306; Cruzado 2016) ${ }^{12}$. En la segunda exposición parisina de 1900, España colaboró con un pabellón propio, de estilo renacentista, escaso contenido y tono castellano, acorde a una apuesta regeneracionista fajada frente al tópico, a pesar de lo cual acogió una "taberna flamenca donde se baila zapateado" (La Ilustración Espanola y Americana 15 mayo 1900: 287). Cierto es que el objetivo inicial de la delegación española pasaba por romper los viejos arquetipos y proponer una visión industrial y avanzada del país. Pero en poco ayudó que la organización presentara por su cuenta la atracción L'Andalousie au temps des maures que, en un magno entorno distinto al del Pabellón Español y compartido con otros de "países exóticos", incluía entre otras recreaciones del Alcázar sevillano, la Alhambra y el Sacromonte. Para satisfacción de los asistentes y su idea de España, el recinto proponía "asaltos a caravanas, bodas gitanas y actuaciones de grupos flamencos y bailarinas españolas; y todo presidido por una Giralda totalmente dorada a la que se podía subir en burro" (Sazatornil y Lasheras 2005: 286). La experiencia se completaba con diversas ofertas de aire "moro" mezcladas con las andaluzas.

Una diversidad de voces se alzó en torno a la participación española. Para Alfonso de Mar, corresponsal destacado en la Exposición, gitanas y gitanos, rasguear de guitarra y cantes y otras "calamidades flamencas" delataban "el españolismo abigarrado que debiéramos esconder como se esconde una úlcera, en vez de exhibirlo con gracia" (ibid). Caso distinto era la crónica francesa de actualidad, que reflejaba la aspiración por conocer otras formas de vida y costumbres, así como los efectos que en la multitud causaba este espectáculo "andaluz" (aquí se regionaliza el apartado) "extrañamente pintoresco y cautivador»:

Résume de la semaine. Nos gravures a l'Exposition. Les danseuses espagnoles.

Si l'Exposition présente des sujets d'étude aussi instructifs que variés, elle offre aussi des divertissements sans nombre et d'incomparables amusements. C'est surtout par ce côté qu'elle intéresse le grand public, et rien n'est, en somme, plus explicable. Ce serait trop long d'énumérer les plaisirs offerts à la foule par la grande fête internationale. Les plus counus sont ceux qui nous font assister à quelques details de la vie ou des moeurs des pays étrangers. C'est ainsi par exemple que la foule se presse au spectacle étrangement pittoresque et captivant des danses andalouses que représente notre dessin (L'Express de Lyon Illustré, 17 junio 1900: 2).

Vayamos al registro cinematográfico y documental de estas danzas. El evento parisino de 1900 concitó un buen número de filmaciones de aspectos parciales: cabalgatas, edificios, paseos, actos y representaciones... Téngase en cuenta que, además de las instalaciones, en el recinto se contrataban todo tipo de eventos temporales y actuaciones, muchas de ellas danzas "exóticas" o "pintorescas". De esta guisa serían las que

\footnotetext{
${ }^{12}$ Es significativo que Manuel de Falla afirme de Débussy que "el conocimiento que adquirió de la música andaluza fue debido a la frecuencia con que asistía a las sesiones de cante y baile jondo dadas en París por los cantaores, tocaores y bailaores que de Granada y Sevilla fueron a aquella ciudad durante las dos últimas exposiciones universales allí celebradas» (Falla 1988: 176-177).
} 


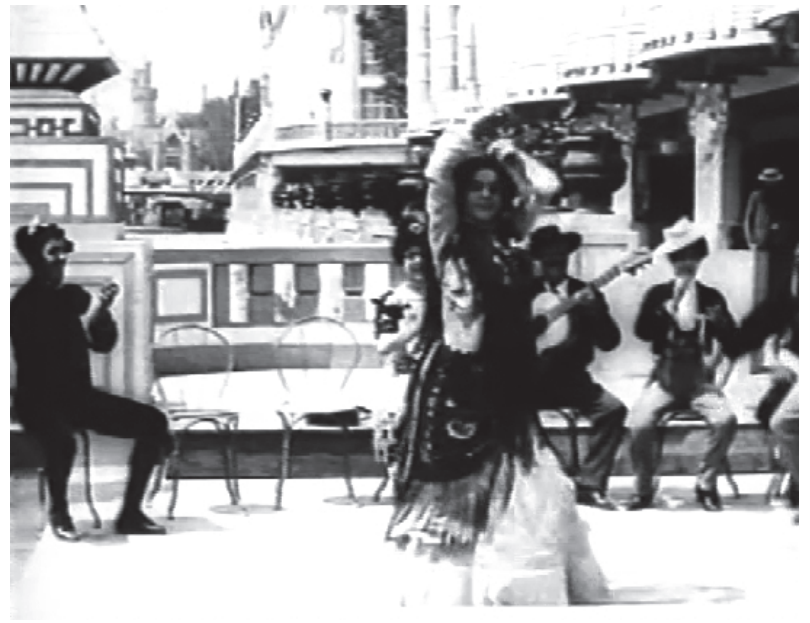

ImAGen 2.-Danse espagnole de la feria Sevillanos, 1900. Original Hermanos Lumière. Fotografía recuperada de $<$ http://www.criticalcommons.org/Members/kfortmueller/ clips/danse-espagnole-de-la-feria-cuadro-flamenco-1900/view> para objetivos de investigación (excepción legal de cita, DP). la empresa de los Hermanos Lumière rodó en exteriores, producidas en gran formato y que recogen bailes flamencos. Sabemos que nada más iniciada la Exposición en el mes de abril, se desplazó a París una troupe flamenca contratada en Granada y Sevilla a través de Juan Amaya y José Segura. Estaba formada por ocho y catorce artistas respectivamente, y fue contratada para siete meses. Entre sus integrantes se documentan no sólo bailaoras, sino también guitarristas, bandurristas y gitanas granadinas que dirían la buenaventura ${ }^{13}$. Sin embargo, no debieron ser los que integran nuestras filmaciones, en repetidas ocasio-

nes atribuidas a la compañía del Maestro Otero y muy recientemente identificadas con un conjunto de intérpretes entre los que se integra el Mulato Meric (Mora 2016).

El cuadro se presenta con orquesta ("estudiantina") de guitarras y bandurrias españolas en el entorno de la ribera del Sena. Con alguna figura cortada a la derecha del plano, en Danse espagnole de la feria Sevillanos (1900) el encuadre abarca el total del grupo formado por cuatro hombres y tres mujeres: dos "esquineros", la bailaora de la pieza, dos palmeras vestidas de flamenca y traje masculino, un guitarrista y un bailaorbailarín, ataviado como majo [Imagen 2]. Son los mismos intérpretes de la escena siguiente, lo que evidencia una rotación habitual en los profesionales de la época. La cámara se mantiene fija y de frente durante el registro; no aspira a recorrer las figuras ni a centrar la simetría de la ejecución. La danza, posiblemente un tango flamenco, es una sucesión de marcajes, paseos y llamadas hasta que quien hasta entonces se nos aparece como cantaor de una letra corta, el Mulato Meric, salta y entra en la escena como bailaor típico, aunque integrando alguna mudanza de tono taurino, para iniciar seguidamente el paso a dos. Se pueden reconocer los jaleos de la bailaora, los "pitos" o chasquidos de los dedos (la castañuela ya no está presente en el flamenco; sí en los bailes boleros), los "vacuneos" de caderas femeninos con alternancia de cabeza, una pasada y una vuelta de pecho de la joven bailaora. Su indumentaria y adorno responden a la larga y acampanada falda de volantes, mantón grande cruzado tapando el pecho y blusa de manga rematada hasta las muñecas. Este retrato "a lo gitano"

13 González Alcantud 2016. Mónica Barrientos ha documentado coetáneamente la compañía de este José Segura alternando con variedades y baile (Sr. Bermúdez, Concepción Fernández, maestro Pericet y pareja infantil Hermanos Palacios) en los salones de la calle Sierpes de Sevilla, durante sesiones combinadas con el cinematógrafo (Barrientos 2006: 99). 
destila la moralidad de la apariencia sincera que Leguen reconoce para la sociedad decimonónica (Luengo 2013: 12), por comparación a la hipersexualización de un cuerpo exhibido de forma erotizante antes que típica característica de otras bailarinas "a lo español" filmadas en este mismo periodo, como Carmencita [Imagen 3] o la Bella Otero.

Para Danse espagnole de la feria cuadro flamenco (1900), con título intercambiado posiblemente con el registro Sevillanos, contemplamos una serie de dos sevillanas interpretadas por los mismos figurantes sobre idéntico escenario escalo-

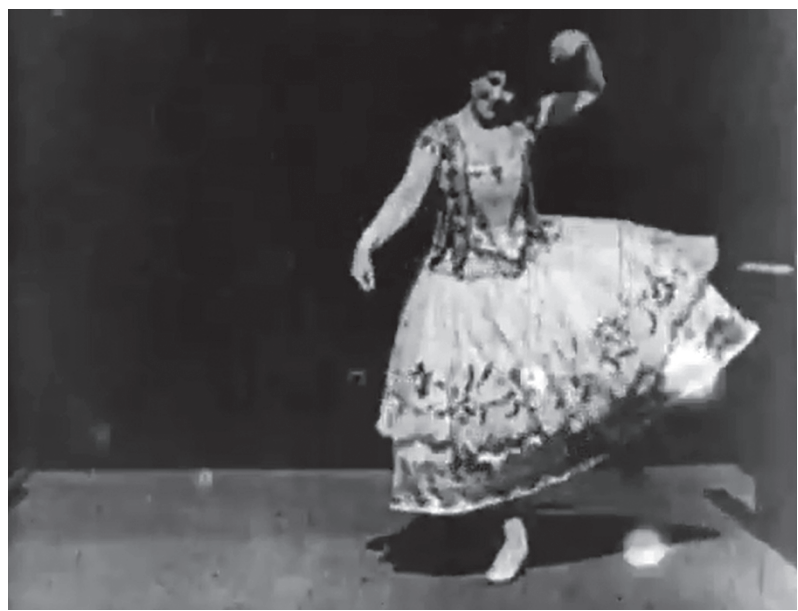

IMAGEN 3.-Carmencita, 1894. Original W., Thomas A. Edison, I. \& Hendricks. EEUU: Edison Manufacturing Co] Fotografía recuperada de [Video] Library of Congress, https://www.loc.gov/item/00694116 para objetivos de investigación (excepción legal de cita, DP). nado. El formato de orquesta de pulso y púa incluye ahora rondalla de seis bandurrias y cuatro guitarras. La pareja pierde la frontalidad a cámara con la que se inició el número anterior, y sugiere un protagonismo compartido y pautas boleras más estructuradas: pasos de sevillana, rodazanes, saltos, pasos de elevación, vueltas, pasadas por delante y "bien parao" definen la coreografía. De nuevo, el tamaño de campo es equivalente al objeto visual, los fotogramas carecen de medios y primeros planos, no se individualiza el rostro, y los límites visuales del cortometraje coinciden aproximadamente con el plano-figura de visión completa, también aquí cortada. Solo la mayor amplitud en la línea de horizonte deja ver alguna perspectiva monumental de la Exposición. La sensación de producción intercambiable e indistinta entre registros es característica de estos formatos primitivos. La credibilidad del documento se obtiene según las acciones reales emergen para la cámara, y el operador se limita a la selección del contenido. Cada plano es una secuencia en sí misma, en ausencia de cambios o prácticas de montaje. Se trata de tomas sencillas, brutas, que sostienen la visión del primer disparo y carecen de cierre: las disonancias entre la duración de la acción y de la filmación se resuelven según criterios de oportunidad. El objetivo es impresionar el movimiento sobre la escenografía disponible, sin ningún protocolo ni expectativa documentales.

\section{EL FOCO NORTEAMERICANO, 1901: ¿GITANAS EN BUFFALO?}

En Estados Unidos, ya en 1888 se tiene noticia de algunas filmaciones cinematográficas de Thomas Alva Edison, cuyo asistente William Kennedy L. Dickson comenzó a desarrollar experimentos sobre máquinas de filmación y reproductoras entre 1889 y 1892. Perfeccionados los sistemas de impresión y patentados los aparatos, Edison 
Manufacturing Company comenzó a filmar en 1890 en los pabellones anejos a los laboratorios Black Maria, para continuar con rodajes en exteriores.

En 1901 el catálogo de Edison pone a la venta por 9 dólares el rollo Spanish Dancers at the Pan-American Exposition, una atracción del evento que tuvo lugar en Buffalo. La ficha describe una escena "both artistic and entrancing" realizada en la "Gypsy tent" de la exposición con una troupe de "ten beautiful Gypsy girls executing the famous Gypsy dance that created such a furor at the Exposition" ". La toma, del dia 28 de octubre, muestra a las muchachas vestidas de forma costumbrista ejecutando unos bailes más bien anárquicos. Es una escena descontextualizada que reitera lo dicho respecto a cámara fija, ausencia de estructura de cierre, plano de angulación normal, recorte de figuras y escenificación provista, no planificada [Imagen 4].

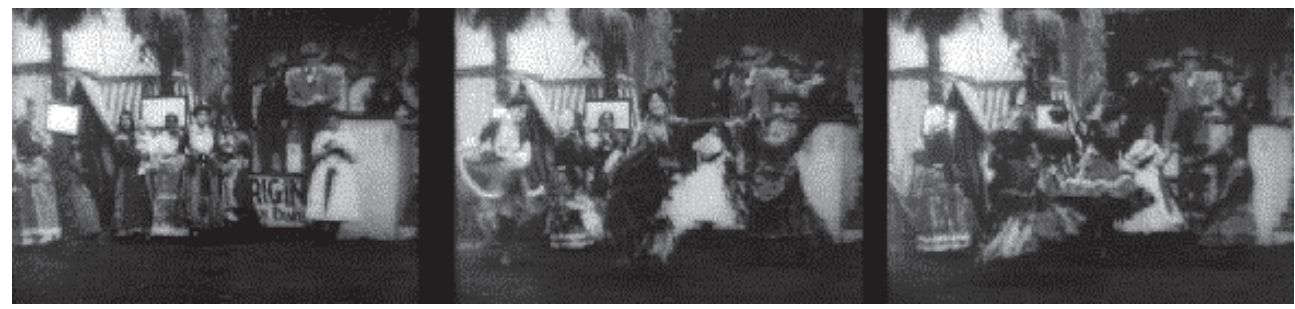

IMAGEN 4.-Spanish dancers at the Pan-American Exposition, 1901. Original Thomas A. Edison, I. \& Paper Print Collection. EEUU: Thomas A. Edison, Inc. Fotografía recuperada de [Video] Library of Congress, https://www.loc.gov/item/00694361 para objetivos de investigación (excepción legal de cita, DP).

La segmentación de los personajes perfila no obstante algunas diferencias con películas coetáneas. Al fondo, cuatro mujeres de tez oscura, una de ellas con un bebé en brazos, asisten y parece que "adornan" el cuadro, vestidas con largas faldas y pañuelos en la cabeza que confieren tinte agitanado a los fotogramas. Su papel decorativo es tal que, aunque intentan moverse a compás, puede vérselas carcajeándose detrás del abigarrado grupo de bailarinas. Si se trató de gitanas auténticas o de mujeres disfrazadas de tales es un enigma, aunque se advierte un faldón que las publicita como Original Gypsy Dancers ${ }^{15}$.

Respecto a las supuestas gitanas que bailan en la zona delantera, las ejecuciones incluyen formas aboleradas elementales con castañuelas, giros, vueltas y saltos. Se entrevén algún esbozo de cambrés, reiterados développés impropios del baile español, así como elementos integrados del can-can, una danza entonces de moda en Francia. Las manos todavía aparecen sin remolinos, pinzas ni arabescos, pero algunas mudanzas son claramente aflamencadas, como los movimientos de pequeños espacios

${ }^{14}$ Disponible en: <http://www.loc.gov/item/00694361/>. Fecha de acceso: 10 en. 2015.

${ }^{15}$ El Catálogo de la Exposición no ofrece datos y recoge solo tres tipos de representaciones de danzas, todas ellas en la zona The Midway: en las "Streets of Mexico" se mostraban artesanos y bailes de "native fandango", en "The Old Plantation", doscientos "genuine southern darkies" bailarían y cantarían "exactly as the negroes of the south used to do in the long ago", y también se interpretaría la "fire Dance", tenida por una de las más pintorescas, que se había ganado los favores del público. No obstante, señala que habrá una descripción más amplia de actividades, «both from a moral and a amusement standpoint, entre las que debió encontrarse esta atracción ("PanAmerican Exposition" 1901: 26-28, 31 y 34). 
en que se marcan y destacan las caderas, con sugerentes e incitantes técnicas de "Vacuneo" y vaivén, o los brazos a la española en cuarta posición. En particular, se adivina el modelo a la derecha de la imagen, una bailaora con castañuelas vestida con falda larga de volantes, mantoncillo y delantal, cuya estética contrasta con las formas más dinámicas de la izquierda y el frente.

Spanish Dancers... evidencia la condición promiscua de las artes del espectáculo en este periodo, donde la realidad de costumbres se deforma con mezcolanza de géneros y estilos y se concentra en retazos iconográficos más o menos inventados. La siempre deslizante cuestión de la autenticidad (qué eran lo bolero, lo flamenco, los bailes populares, qué las variedades o las danzas clásicas) no fue asunto exclusivo de estas exhibiciones, sino del concepto escénico propio de la época:

no fue solo el baile español la única 'víctima' en el auge de las varietés y espectáculos de music-hall, también lo fueron otros bailes y danzas considerados exóticos, algo que siempre sumaba puntos a favor del nuevo modo de espectáculo, ávido por mostrar a los sorprendidos espectadores todo aquello que les era lejano" (Marinero 2012: 281).

Precisamente, se ve en la película a un maestro de ceremonias elevado en un practicable que, con ademanes publicitarios, gesticula en la entrada al frente del pabellón. Las bailarinas funcionan a modo de reclamo del nutrido grupo de hombres (todos menos una figurante) que pagan la entrada a la barraca. Mujeres desconocidas, posiblemente miembros de la nutrida pléyade de españolas o no tanto, reclutadas para la aventura transoceánica a la búsqueda de una proyección profesional que en unos casos llegaría y en la gran mayoría las dejó reducidas al género ínfimo: en estas fechas, el retrato de la gitana española se enunciaba a la par en los textos por su marca racial de "pureza" y por su relativa disponibilidad sexual (Charnon Deutsch 2004: 71).

\section{DRAMATIZACIONES TEATRALES}

Las películas anteriores llevaban al espectador bailes practicados, al menos teóricamente, por artistas patrios. Otra serie de filmes —en este caso, filmados in situ en los teatros- son protagonizados por copistas. Evocan los aires, recursos o argumentos ambientales en el marco de dramatizaciones dancísticas, pantomimas, cuadros cómicos y relatos narrativos.

Según la ficha de registro, la película El Cid (1900) tiene como intérprete distinguida a la estelar bailarina de la Ópera de París Carlotta Zambelli, acompañada de Michel Vasquez. La pareja bailaría una habanera sobre música de Jules Massenet. Con un decorado de columnas y macetas que quiere representar un pintoresco patio de Andalucía, el baile principia con una presentación de la bailarina y, a continuación, se representa el paso a dos. La indumentaria es clásica en su funcionalidad (zapatilla y tejido ceñido), aunque incorpora detalles de españolidad: la bailarina se embute un cuerpo abolerado y una amplia falda con volante que expande el tutú, y se peina con flor baja; Vasquez viste calzas, chaquetilla corta, chaleco de majo y camisa blanca con puños de chorrera. Ambos se tocan con sombreros; ella, una montera que arroja en un momento de la ejecución; él, un catite que se quita y se pone dejando adivinar un pañuelo anudado en la cabeza. 
El cuerpo central de la exhibición consiste en realidad en una tanda de cuatro (probablemente) seguidillas o boleras, en las que se suceden saltos, "bien paraos" y trenzados, aunque también hay subidas de la bailarina, vueltas de cigüeña y puntas que sustituyen a los zapateados. Aunque no se usa la castañuela, la referencia al "Pas de la Castillane" casa mejor con lo que se muestra en la película. Las piezas principian con una presentación, posiciones encaradas, y en las dos últimas seguidillas encontramos el hoy conocido como "paseíllo de sevillanas". El carácter de imitadora de Zambelli se advierte en las posiciones de un brazo en quinta y el otro a cintura, séptima alta, de segunda a quinta con cambré y a la cintura. Pero el clasicismo académico impregna toda la interpretación. Siendo la figura de Vasquez más redonda y recogida, más en el tono español, la ejecución es muy similar entre ambos: cuidadas posiciones de brazos, blandos y redondos, manos sin arabescos, saltos, embotados, bordoneos, sostenidos, destaques y altos développés.

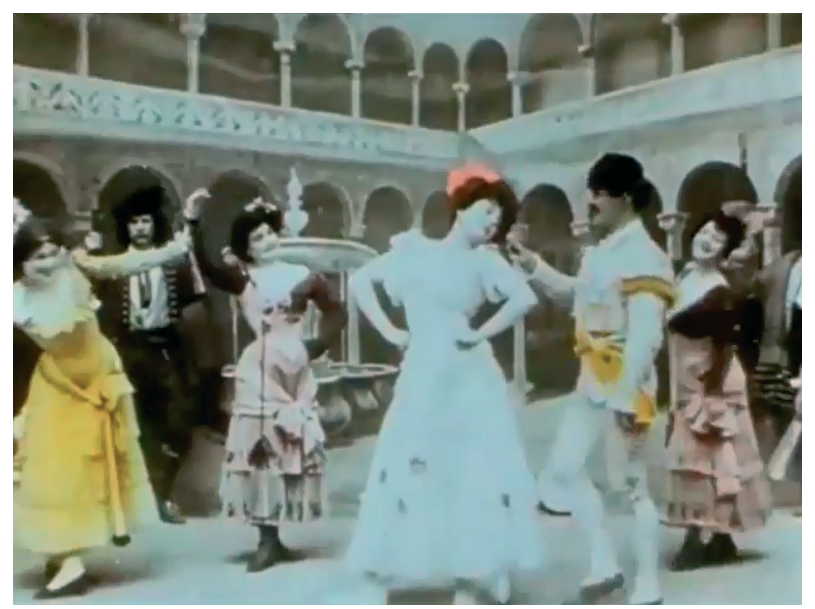

IMAGEN 5.-Terpsichore o Le Ballet de Terpsichore (Saberet. Le boléro), 1900. Original: Gaumont-Pathé. Fotografía recuperada de [Video] <https://www.youtube.com/watch?v=G7cpV9L5d84> para objetivos de investigación (excepción legal de cita, DP).

Terpsichore o Le Ballet de Terpsichore (1900) es tal vez de los más conocidos metros fílmicos de la casa Gaumont, gracias a su restauración en el año 2012. En su cartela se califica como mariage aux flambeaux, y es frecuentemente reproducido como Saharet, le boléro. Dudosamente atribuido a la pionera directora francesa Alice Guy, que la habría dirigido en la misma fecha que Le boléro cosmopolite, el registro representa el mito de forma inocente y tamizado por la figura de Carmen, cuya publicación y representación estructuró de una manera convencionalizada las ideas y los perfiles arquetípicos españo-

les, tanto masculinos como — sobre todo- femeninos. La cinta está coloreada en la postproducción, técnica frecuente en el periodo para los cortometrajes más destacados, marcando el rojo de la flor en el pelo para la primera bailarina [Imagen 5].

Sobre el decorado de un señorial patio andaluz alhambresco, forman el cuadro dos boleras con trajes rosados y otras tantas con ropajes amarillos; las cuatro calzan tacones. La protagonista viste falda blanca a la pantorrilla de volantes espumosos, baila en zapatillas y porta castañuelas. Una figurante travestida en hombre, con bigote pintado y traje de torero, y el bailarín único, con fajín coloreado y montera de falsas orejeras que vuelan ridículamente a cada salto, completan el elenco. Tras un primer paseo con despliegue de abanicos, el baile arranca con el paso bolero de dos jóvenes que terminarán tirándose al suelo, produciendo el primero de los diez cuadros estáticos que identifican este número. Huidas y retornos se suceden entre el torero y 
la intérprete principal, así como pasadas, saltos y pequeñas dramatizaciones, con detalles como pandereta, palmas y posiciones intravertidas y quebradas a tierra para imitar el estilo español. En la última parte, el bailarín enlaza sucesivas vueltas, trenzados y giros casi acrobáticos. Anecdóticamente, ambos registran pérdidas de equilibrio, pues las técnicas de rodaje no permitían repetir escenas.

\section{PANTOMIMAS Y PARODIAS}

No es habitual encontrar referencias fílmicas a "lo español" como objeto de chanza en los espectáculos de género parisinos de la época, una evidencia del desprestigio con el que se contemplaban estas prácticas, parejo a su atracción irresistible. Pero así debió de ser en el teatro, a tenor de los numerosos grabados, fotografías, crónicas y guiones de vaudeville con localizaciones, fonética y caracterización de los personajes que se conservan en otras fuentes históricas (Ramos Gay 2006) y de estos dos relevantes documentos que aportan los GPA.

Danse époque 1910 es un número de variedades cantado por lo que en España se conocía como "cupletista", y descrito como extravagante (style espagnol plutôt fantaisiste) en la base de datos del archivo. Debió contener una canción narrativa e hilarante, a tenor de los gestos de sueño y otras actitudes jocosas concatenadas en la película muda. Seguramente fue una sátira del estilo español, cantada por Margherite "Elgé" quien, peinada con dos flores a los lados y un traje de variedades, en actitud declamatoria, adopta posiciones, paradas, puntas y, al final, una subida de la falda hasta la cara que denotan el sentido burlesco de la interpretación.

Detrás de la cantante, cuatro mujeres acompañan el ritmo con pasos y figuras. El transformismo está presente en dos de ellas, que se visten de majo (la inflación femenina en el arte de Terpsichore es bien conocida) mientras otras tantas portan mantilla y falda a la pantorrilla. Las mudanzas reproducen a su forma el patrón de la danza española: caminan a paso de marcha, realizan inexactos braceos a la cuarta, forzados movimientos de caderas, pequeños saltos y paradas, pasadas boleras o ruedas a dos.

Little Tich realiza dos parodias de baile español en los cortometrajes contenidos en GPA, lo que da fe de la popularidad de este pequeño cómico inglés que hacía del histrionismo su escuela. Aunque especialmente célebre por su Big Boots Dance, con botas de largas suelas, Little Tich desarrollaba números muy variados; entre ellos, estas imitaciones de chusco transformismo.

La excentricidad de los números de parodie de danse espagnole (1907) debía expresar lo que se entendía como denominador común del baile nacional, limitado aquí a algún detalle indumentario y ciertas mudanzas. En particular, el movimiento del chal a modo de mantón, deslizamientos, giros, saltos, figuras, brazos redondos, juego de caderas, vueltas, intraversión y puntillosos zapateados de carrerilla, en actitud sugerente.

\section{BAILES EN PELÍCULAS NARRATIVAS}

De entre las muchas producciones de tono folletinesco conservadas y accesibles que hacen presente el aire español con connotaciones gitanas o del género andaluz y 
evocación del mito de Carmen, fechamos la primera en la década de 1900. Sin más datos de registro, se encuentra en los HFA y bien pudiera ser una de las películas referenciadas en otras fuentes, aquí con una denominación reveladora: Matador Romance. Un baile de pareja femenino inicia el cortometraje: pasadas con posición frontal, figuras curvadas introvertidas, vueltas y braceos, y un sorprendente movimiento zigzagueante de la falda arremangada de una de las bailaoras, que acaba con un "rodillazo" en el cierre en "bien parao" de la pareja, pintan el mínimo esperable de la danza nacional. El grupo concitado en la taberna las jalea con palmas y toque de pandereta (instrumento que estaba prácticamente desaparecido de los verdaderos escenarios flamencos: los cafés cantantes). El aderezo, por supuesto, lo pone la indumentaria de mantón, sombrero y mantilla (también desaparecida en el flamenco, pero vigente en los números de cuplé aflamencado de la época), falda de volantes con amplia enagua a media pierna para las mujeres, y los trajes campero y de matador de toros para los actores masculinos. Éstos se enzarzan en la pelea a navajazos característica, complementando el montaje un posible injerto de una auténtica corrida de toros que, necesariamente, termina con la muerte del matador.

El argumento de Le Deserteur (1906) gira en torno a un suboficial que conoce en un pueblo de guarnición a una licenciosa bailarina, cuyas aspiraciones pasan por el dinero. El joven — que no lo tiene-, se enamora perdidamente de ella, perpetra un robo y le pide que huyan juntos, disponiéndose a desertar del ejército. Finalmente, los gendarmes detienen al soldado y lo llevan a la cárcel, donde se suicida preso de culpa y vergüenza. El principio de la película expone un café concierto de la época, que nos recuerda grabados y fotografías de los primeros cafés cantantes flamencos. La clientela, compuesta fundamentalmente por la soldadesca, bebe mientras en el pequeño escenario se apiñan las bailarinas, que van sucediéndose en las tablas. La primera actriz hace su número, desciende hasta las mesas e incita a los entusiasmados clientes. Otra acomete "une danse espagnole très applaudie" que tiene de español apenas el hecho de que sale a bailar con una pandereta y ciertas figuras y posiciones quebradas. No obstante, la adscripción moral casa con su condición de artista, esto es, mujer degenerada y astuta cuya belleza y capacidad de seducción ponen en peligro la rectitud y formalidad del ingenuo militar.

El corto Sang espagnol. La gitane (1908) narra una historia de celos y sangre. Los reclamos del título son suficientemente evocadores de la estela de género andaluz y de un discurso sobre cante y baile que pasará de forma directa al cine del siglo XX a través del espejo flamenco. La referencia a la gitana ahonda en el estereotipo según el cual "Los gitanos eran exactamente los individuos socialmente periféricos que tenían sentido en cualquier búsqueda etnográfica del "color local" (Bennahum 2013: 20).

La historia se construye entre la esposa (decente) de un torero-bandolero más bien licencioso y su casquivana amante, cuyo cigarro encendido — metáfora de la desahogada cigarrera sevillana- se convierte en imagen del vicio ${ }^{16}$. Cuando, apercibida de

\footnotetext{
${ }^{16}$ Conviene recordar la asociación entre tabaco, mujeres y gitanos como signo de poder y libertad que defiende Klein, para quien "among women, smoking began with those who got paid for staging their sexuality: the actress, the Gypsy, the whore. Such a woman violates traditional roles by defiantly, actively giving herself pleasure instead of passively receiving it. Lighting a cigarette is a demonstration of mastery that violates the assumptions of feminine pudeur (...) A woman smo-
} 
la traición, la esposa va a buscar a su marido, se produce una escena de pelea navajas en mano, y finalmente el asesinato de la primera.

El filme no es sino una recreación bastante burda limitada a la indumentaria de los actores, poses, acciones y actitudes entrevistas [Imagen 6]. En el cortometraje, como en la representación teatralizada de Carmen,

La escenificación y la interpretación propiamente teatral de la obra padecen del excesivo afán de autenticidad castiza (...) Los tipos populares, los cuadros de

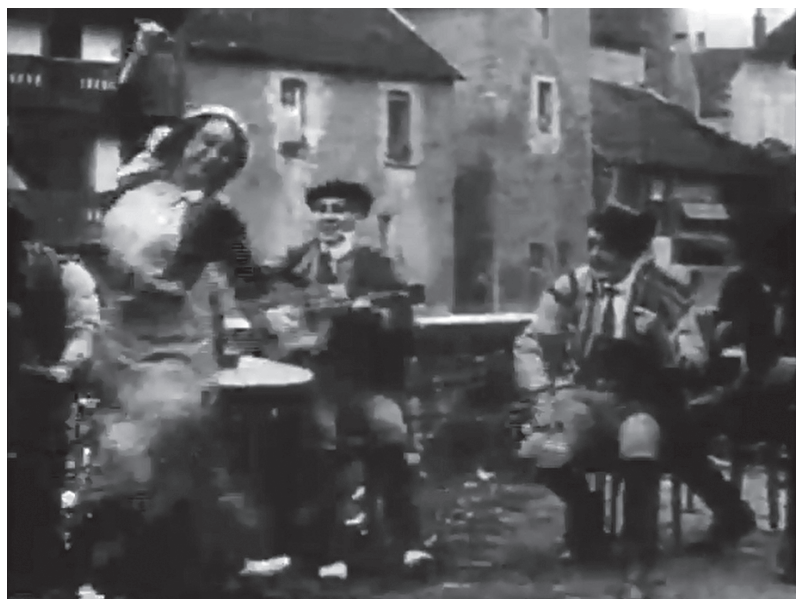

Imagen 6.-Sang espagnol, 1908. Original: Pathé. Fotografía recuperada de [Video] $<$ https://www.youtube.com/watch?v= v3rXEB8g0S8> para objetivos de investigación (excepción legal de cita (DP). costumbres, las efusiones

líricas y los lances dramáticos interesan más que el desarrollo de la historia trágica como tal (Sentlaurens 2002: 865).

Ni el caserío ni la ambientación recuerdan a Andalucía, pero los personajes sí son fieles al arquetipo. Primero, la gitana: una mujer adúltera, que fuma, bebe y baila, lo que sintetizaba la dosis de autonomía y plebeyismo femeninos de la figura literaria de Carmen, ahora también cinematográfica. En seguida aparecen el torero, el guitarrista y el bailaor, un encaje que redondea el cuadro argumental. Claver ha estudiado en el cine el híbrido redondo de todos los actores asociados a películas como esta, apreciando cómo

Con la irrupción del flamenco a nivel nacional se establecerá un nuevo personaje literario, el tipo del flamenco y de la flamenca, cuyos rasgos van a ser la desmedida afición a este género de música y de vida, la inclinación a la juerga, al vino, a la navaja, a la reyerta, al mundo de los toros... que, junto a los majos, trazan una clara evolución literaria que tendrá como punto final el tipo del flamenco (2012: 90).

Un amago dancístico tiene lugar tras unirse la pareja a tres tipos de manta al hombro e indumentaria castiza, acompañados de botellas y guitarras. Uno de ellos entona ciertos pasos boleros y, de inmediato, baila la gitana. Panderetas, palmas y un guitarrillo la acompañan en unos braceos circulares evocadores de la curva española, que rematan con un "bien parao" de rodillas de la pareja. La llegada de la esposa precipita su propia tragedia, y la huida final de los amantes.

Clair de lune espagnol (1909) incluye dos escenas de danza. La primera se desa-

king may be thought to be less "feminine" because more active, aggressive, masterful, but she is not therefore more "masculine" - in her own eyes or in those of many men; she may in fact be more desirable because she appears to be more free" (Klein 1995: 117) 


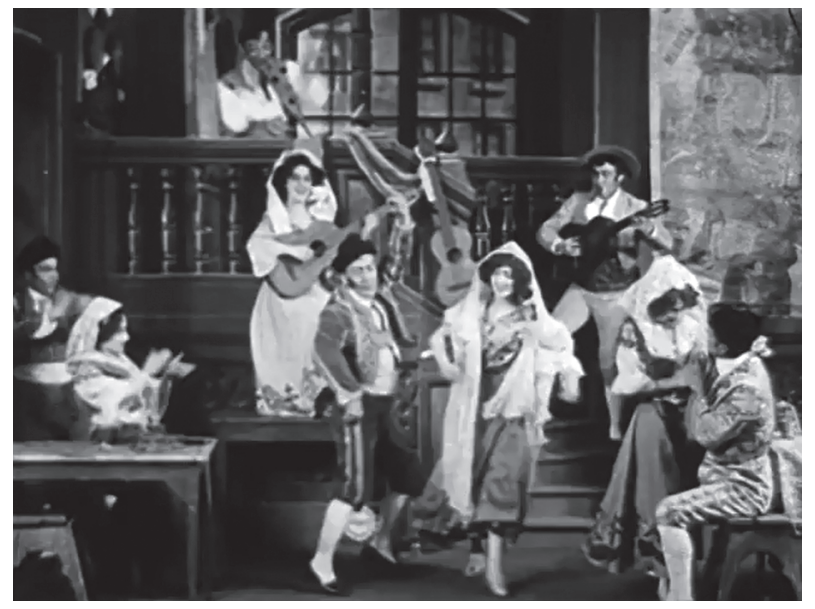

IMAGEN 7.-Claire de lune espagnol. 1909. Original: Library of Congress. Fotografía recuperada de [Video] <https:// www.youtube. $\mathrm{com} /$ watch? $=\mathrm{oQeXV}$ gdMrXw $>$ para objetivos de investigación (excepción legal de cita, DP). rrolla en una posada donde Pedro espera la llegada de su amada. Dispuestos en forma piramidal, varios figurantes animan y jalean a la bailaora. Dos guitarristas parecen tañer los instrumentos con atuendo majo, mientras otros actores tocan la pandereta y las palmas. Al fondo reposa una guitarra decorativa. Varias de las cuatro jóvenes, vestidas con mantilla blanca, fuman, se abanican y alternan en las mesas con los clientes antes de que se desarrolle el enfrentamiento de la pareja. El baile no es sino un recurso mínimo al servicio de la escena de costumbres, pues las puntas laterales, como la vuelta, el giro o la caída a tierra, denotan la copia de un imaginario cinético.

El incoherente desarrollo de la trama propuesto por el animador y caricaturista Émile Cohl desemboca, después del viaje a la luna que inspira el título, en la misma posada. La película es una muestra del cine de efectos ópticos que tendría su mejor expresión en las figuras de Georges Méliès en Francia y Segundo de Chomón en España. El protagonista cae desde el techo vestido de algo parecido a un torero, cuenta su historia para general algarabía, se reconcilia con la amada y principia un atropellado baile. Un figurante inicia el fandango de pareja con otra joven, sosteniendo el paso bolero y el cuerpo redondeado mientras la muchacha gira y termina disponiendo su pie sobre la pierna de aquél, que se tira al suelo. Al fondo, una andaluza parece tocar la guitarra, un actor toca las palmas y jalea mientras otro combina palmadas y posiciones en cuarta redonda bolera. La película termina en este punto, retratando un cuadro de mantillas, chalequillos con lunares, manoletinas, medias y taleguillas (el ceñido pantalón del torero), que como bebida, tabaco, palmas, guitarras, panderetas y personajes remiten inevitablemente al libreto de Carmen desde la imperfección narrativa de la copia ambiental [Imagen 7].

En Le Charme des Fleurs (1910) se reproduce lejanamente la historia de amor de Pedro, el torero, y Carmen, la gitana, al servicio de nuevos trucos fílmicos y de un fondo argumental que suaviza el entorno tabernario de la película anterior, proponiendo fondos de jardines y un requiebro floral. Recientemente restaurada, la película incluye tres secuencias de bailes que impostan el modelo español sobre exteriores urbanos donde no se reconoce conexión con Andalucía. En el primer baile, y en lo que parece un café cantante, la joven Carmen repite mudanzas y posiciones que quieren simular la compostura y braceo a la española, aunque se trata más bien de una sucesión de balones hacia la diagonal lanzando la pierna con tres sostenidos y una serie 
de braceos descuidados y actitudes espasmódicas. La parte final de la secuencia consiste en una caída al suelo y cinco giros en redondo, a modo de souplesse en vuelta como es propio de la coreografía bolera "Ole de la Curra". La actriz continúa con cuatro rodazanes aproximativos alternando las extremidades, dos vueltas con destaque lanzando la pierna, y algo similar a los pasos vascos hasta el final. En su afectada interpretación se confunden las manos cerradas, los brazos caídos, sonrisas y recogidos de la falda, rodeada como aparece de un grupo de toreros y manolas que tocan palmas y panderetas mientras ella muestra desparpajo e impudicia.

En la segunda secuencia se suceden los trucos visuales para un fondo de jardín. Mientras Carmen está dormida, tras el arranque de celos de Pedro, van apareciendo jóvenes musas en torno que componen cuadros estilizados al modo visto en Terpsichore. Después lo hace un trío compuesto por dos guitarristas y un bandurrista, que entonan el baile de una pareja de mujeres en lo que parece un bolero con vueltas, pasadas, careos y otros elementos al uso. Los pasos recuerdan la matalaraña con balones en vuelta, seguidos de balones y dobles sostenidos, pasos vascos girando y un final con dos rodazanes hacia adentro en vuelta.

Tras esta secuencia, la película remata con mímica y expresión por parte de la pareja protagonista, ya reconciliada. Se busca la significación amorosa a través del símbolo floral y una interpretación más bien tosca, con sostenido detrás y tres pasos vascos. Rodeos, figuras agachadas, posiciones estáticas y vueltas en redondo sobre cuartas boleras serpenteadas confieren un tono galante a la exposición sobre la base de careos, "bien paraos" y cuadros estáticos.

\section{SÍNTESIS Y REFLEXIONES FINALES}

Los cortometrajes mudos que constituyen el corpus actualizado sobre bailes españoles, boleros y flamencos hasta 1910 permiten afirmar que los asuntos de danzas "a lo español" formaron parte de los intereses iniciales de las producciones cinematográficas francesa y norteamericana, cuando nuevas técnicas al servicio de la imagen en movimiento convergieron con un contexto de masificación de los espectáculos escénicos. Su análisis pone de relieve el carácter experimental de esta fase del cine y sus todavía imperfectas formas. Los planos generales de cuerpo entero no individualizan ni el rostro ni la "imagen personal" (Mitry 1963: 88), los encuadres se cortan y las figuras se fragmentan. Dado que no existía una escaleta narrativa, las películas, a veces incompletas, son más bien una asistemática selección de escenas, cerradas en su exposición y cuyo contenido se presenta sin edición ni montaje, excepto por el coloreado manual.

Respecto del nivel dancístico, la versatilidad y mezcolanza de las formas populares y "popularizadas" (boleras, flamencas, estilizadas, de music-hall y variedades) fueron una realidad de la que el cine se sirvió en sus producciones mudas, donde es fácil diferenciar la ejecución original de las bailarinas "nativas" $-\mathrm{y}$ tal vez por ello anónimas- y la reproducción academicista vía mimetismos corporales de las artistas de renombre. Utilizadas como reclamo de dudosa autenticidad, la focalización en las bailarinas establece una continuidad con la literatura y la crónica teatral de autores previos: son ellas las protagonistas del relato, y el baile es para el cine un "asunto de 
mujeres", como las acrobacias y deportes, "asuntos de hombres". Aunque estos eran quienes formaban las audiencias dominantes, en el baile son intérpretes minoritarios: en las 16 escenas contabilizados en nuestras trece películas, 70 figurantes son mujeres por 54 hombres, pero son 28 las mujeres y solo diez los hombres que bailan. En cuatro de estos diez casos, además, se juega a la parodia, bien travistiéndose ellas en ellos (probablemente por el déficit de bailarines-hombres) o el cómico profesional en bailarina del país.

Respecto a la construcción cinematográfica de "lo nacional" francesa y norteamericana, el análisis fílmico constata discursos y narrativas que comunicaban un orden jerárquico sobre una geografía y una cultura alternativas. Los contenidos seleccionados habían de ser lo suficientemente atractivos como para responder a una audiencia ansiosa de particularismos y diferencias locales. En el seno de las exhibiciones del "progreso humano" que representaron, por ejemplo, las exposiciones universales, la pasión por el exotismo y la incorporación de las culturas coloniales al presente histórico fueron una marea de acontecimientos contemporáneos al nacimiento del cine. La escenificación de ambientes y costumbres vinculadas al imaginario sobre España jugó un papel equiparable al que el viaje literario detentó desde el siglo XVIII: una forma de turismo visual, ahora sin moverse del asiento (Gubern 2004; Rey 2013).

El análisis demuestra que la filmografía pionera renunció a problematizar sobre los debates reformistas contemporáneos en España; tampoco atendió a su diversidad identitaria, salvo para erigir un monopolio de corte costumbrista donde "lo español" y "lo andaluz" aparecen como etiquetas indiferenciadas. Todos los bailes registrados en el cine primitivo son andaluces, tanto en su estética como en estructura y representación de escenas y figurantes. Este será el sustrato cinematográfico de la españolada, que recoge la carga acumulada del romanticismo y que en apenas unos años será incorporada sin ambages a la factura del cine de ficción de trasunto andaluz, tanto de producción española como foránea.

El procedimiento final es una síntesis de protagonistas y figurantes (el torero, la cigarrera, la bailaora, la gitana, el guitarrista...), y de elementos descriptivos y narrativos (indumentaria, aspecto, funciones, instrumentación, disposición escénica, movimientos...) que formaron parte de una misma familia de significados de gran potencialidad icónica. En esta etapa muda, fueron las acciones más sugerentes, las danzas, y los elementos externos, muy visuales como mantilla, traje de majo, pandereta, manta, guitarra, zapatilla bolera, cigarro, flor, mantoncillo, navaja, larga falda y castañuelas...) los que connotaron en mayor grado referencias de identidad ${ }^{17}$.

Pero la imagen de "lo español" se consiguió en la cinematografía de los inicios no solo a través de la tierra, de la patria, sino también del género - la fascinante condición femenina- y de la raza, de la etnicidad, de "lo gitano". En particular, las bailarinas finiseculares dotaron de un valor añadido nacional-sexual-racial al eje articulador del movimiento, y celebridades o no tanto que menudeaban por los escenarios de la

\footnotetext{
${ }^{17}$ Lou Charnon-Deutsch abre su capítulo "El descubrimiento de la romántica gitana española" con esta cita de Davillier en L’Espagne: "¿Eres española? ¡Enséñame tus castañuelas!”. La anécdota ejemplifica la relación establecida entre este complemento y la españolidad, como una equivalencia necesaria (2004: 45). Sobre la castañuela y la construcción de la identidad española, consultar Cavia (2012).
} 
época, preñadas de encanto visual, protagonizaron cortometrajes donde personificaban la fijación por los cuerpos característica del fin de siglo, de los que se desprendía una lectura comportamental y psicológica generizada y etnizada. Incrustadas en la definición de un "carácter español" que —en el caso femenino- consolidaba el mito de Carmen, la desinhibición, la moralidad alternativa y el cuerpo representaban el alojamiento de una voluptuosidad natural e insalvable, propia de las mujeres y propia de las gitanas, que selló las soñadas marcas hispánicas.

La danza fue la performance que articuló y materializó estas lecturas múltiples sobre la identidad. Mujeres del país, gitanos, tierra y nación encarnaban, por razones distintas, una posición compartida como bienes simbólicos de una oferta a la vez erótica y colonialista, como sujetos menores devaluados, pero indispensables para responder al deseo de los nacientes públicos del celuloide.

\section{BIBLIOGRAFÍA CITADA}

Alonso, Celsa et al. 2010. Creación musical, cultural popular y construcción nacional en la España contemporánea. Madrid: Instituto Complutense de Ciencias Musicales.

Álvarez Junco, José. 2003. Mater dolorosa. La idea de España en el siglo XIX. Madrid: Taurus.

Álvarez Molina, Sandra. 2006. "París: "mecenas" del flamenco finisecular", en Manuel Bruña et al. (eds.), La cultura del otro: español en Francia, francés en España: 300-308. Sevilla: Universidad de Sevilla.

Amador Carretero, Pilar. 1996. "El cine como documento social: una propuesta de análisis". Ayer 24: $113-147$.

Andreu Miralles, Xavier. 2009. «Cosas de España! Estereotipos, marginalidad y costumbres nacionales a mediados del siglo XIX". Alcores: Revista de Historia Contemporánea 7: 39-61.

Aubert, Michelle y Jean-Claude Seguin. 1995. La production cinématographique des frères Lumière, CD-Rom. Lyon: Université Lumière.

Barrientos Bueno, Mónica. 2006. Inicios del cine en Sevilla (1896-1906). De la presentación en la ciudad a las exhibiciones continuadas. Sevilla: Universidad de Sevilla.

Barrientos Bueno, Mónica. 2013. "Panorama de recursos en internet para investigar en cine primitivo". Historia y Comunicación Social 18: 481-497.

Beller, Manfred y Joep Leerssen (eds.) 2007. Imagology: The Cultural Construction and Literary Representation of National Characters. A Critical Survey. Amsterdam: Editions Rodopi B.V.

Benet, Vicente J. y Vicente Sánchez-Biosca. 2013. “La españolada en el cine”, en Javier Moreno Luzón y Xosé M. Núñez Seixas (eds.), Ser españoles: imaginarios nacionalistas en el siglo XX: 560-591. Barcelona: RBA.

Benet, Vicente J. 2012. El cine español. Una historia cultural. Barcelona: Paidós Comunicación.

Bennahum, Ninotchka D. 2013. Carmen, a Gypsy Geography. Middletown: Wesleyan UP.

Calvo Serraller, Francisco. 1995. La imagen romántica de España. Madrid: Alianza.

Camporesi, Valeria. 1997. "La españolada histórica en imágenes", en Aitor Yraola (ed.), Historia contemporánea de España y cine: 137-148. Madrid: Universidad Autónoma.

Cavia Naya, Victoria. 2012. La castañuela española y la danza. Baile, música e identidad. Valencia: Mahali Ediciones.

Charnon-Deutsch, Lou. 2004. The Spanish Gypsy: The History of a European Obsession. Pennsylvania: Pennsylvania UP.

Claver Esteban, José M. 2012. Luces y rejas. Estereotipos andaluces en el cine costumbrista español (1896-1939). Sevilla: Centro de Estudios Andaluces.

Colmeiro, José F. 2003. «El Oriente comienza en los Pirineos (la construcción orientalista de Carmen)". Revista de Occidente 264: 57-83. 
Cruces Roldán, Cristina. 2015. "Presencias flamencas en los Archivos Gaumont-Pathé. Registros callejeros en la Granada de 1905", en José Cenizo y Emilio Gallardo (eds.), Presumes que eres la ciencia: Estudios sobre arte flamenco: 15-43. Sevilla: CDMA/LCD.

Cruzado, Ángeles. 2016a. "Juana la Macarrona en los escenarios europeos (I)". Flamencas por derecho. Disponible en: <http://www.flamencasporderecho.com/juana-la-macarrona-europa-i/>. Fecha de acceso: 14 jun. 2016.

Cruzado, Ángeles. 2016b. "La muchacha malagueña que quería ser torero y conquistó Europa con su baile", en José Luis Ortiz Nuevo, Ángeles Cruzado y Kiko Mora, La Valiente. Trinidad Huertas "La Cuenca": 11-213. Sevilla: Libros con Duende.

Davies, Ann y Phil Powrie. 2006. Carmen on Screen: An Annotated Filmography and Bibliography. Newcastle: Thamesis Books.

Falla, Manuel de. 1988. Escritos sobre música y músicos, Madrid: Espasa Calpe.

Gaudreault, André. 2006. "From 'Primitive Cinema' to 'Kine-Attractography', en Wanda Strauven (ed.), The Cinema of Attractions Reloaded: 85-104. Amsterdam: Amsterdam UP.

Gautier, Teófilo. 2006. Viaje por España /1840/. Valladolid: Maxtor.

Ginsburg, Faye D., Lila Abu-Lughod y Brian Larkin (eds.) 2002. Media Worlds. Anthropology on New Terrain. Berkeley: California UP.

González Alcantud, José A. 2016. "Andalucía 'en el tiempo de los moros'. Andalucía en la Historia 52: 50-56.

González, Palmira. 2005. Los inicios del cine en España (1896-1909): La llegada del cine, su expansión y primeras producciones. Recursos E-excelence. Disponible bajo demanda en: <http:// www.liceus.com/bonos/compra1.asp?idproducto $=704 \&$ los-inicios-del-cine-en-espana-18961909\%29-la-llegada-del-cine-su-expansion-y-primeras-producciones>. Fecha de acceso: 07 en. 2015.

Griffiths, Allison. 2002. Wondrous Difference: Cinema, Anthropology, and Turn-of-the-Century Visual Culture. Nueva York: Columbia UP.

Gubern, Román. 2004. "Del imaginario turístico al imaginario colonial", en Àngel Quintana et al. (eds.), Imatge i viatge. De les vistes òptiques al cinema: 23-26. Girona: Museu del Cinema.

Gunning, Tom. 1986. "The Cinema of Attractions: Early Film, Its Spectator and the Avant-Garde». Wide Angle Vol. 8 (3, 4): 63-70.

Gunning, Tom y André Gaudreault. 1989. "Le cinéma des premiers temps: un défi à l'histoire du cinéma?", en Jacques Aumont, André Gaudreault y Mochel Marie (eds.), Histoire du cinéma. Nouvelles aproches: 49-63. Paris: Sorbonne.

Jost, François. 1996. "La invención del cineasta". La comunicación audiovisual en el mundo contemporáneo. Buenos Aires: U Palermo.

Juliá, Santos. 2004. Historia de las dos Españas. Madrid: Taurus.

"La Exposición Internacional de París", La Ilustración Española y Americana, 15 mayo 1900. 12 octubre 2014.

Klein, Richard. 1995. Cigarettes Are Sublime. Durham: Duke UP.

Lavaur, Luis. 1976. Teoría romántica del cante flamenco. Madrid: Editora Nacional.

Leerssen, Joep. 2007. "Imagology: History and Method", Beller y Leerssen, op. cit: 17-33.

Leerssen, Joep. 2012. "La retórica del carácter nacional. Un panorama programático", en Nadia Lie, Silvana Mandolessi y Dagmar Vandebosc (eds.), El juego con los estereotipos. La redefinición de la identidad hispánica en la literatura y el cine postnacionales: 57-86. Bruselas: Peter Lang,

"Les danseuses espagnoles". Le Gaulois: littéraire et politique. 10 janvier 1880. Disponible en: <http:// gallica.bnf.fr/ark:/12148/bpt6k5233190.item>. Fecha de acceso: 24 jul. 2014.

Llano, Samuel. 2013. Whose Spain? Negotiating "Spanish Music" in Paris, 1908-1929. Oxford: Oxford UP.

Luengo López, Jordi. 2013. "Belleza femenina y arte de mujer en Consuelo de George Sand". Revista de estudios filológicos 25. Disponible en: <http://www.um.es/tonosdigital/znum25/secciones/ tritonos-2-luengo_consuelo_de_gsand.htm>. Fecha de acceso: 16 abr. 2014.

Machado y Álvarez, Antonio. 1881. Colección de cantes flamencos, recogidos y anotados por Demófilo. Sevilla: Imprenta y Litografía de El Porvenir.

Marinero, Cristina. 2012. "La cámara como coreógrafa o no: apuntes para un análisis sobre la danza española en el cine", en Idoia Murga et al. (eds.), Líneas actuales de investigación en danza española: 279-301. Madrid: Nebrija Fundación. 
Méndez, Lourdes. 2004. Cuerpos sexuados y ficciones identitarias. Sevilla: IAM.

Mitry, Jean. 1963. Estética y psicología del cine. 2. Las formas. Madrid: Siglo XXI.

Mora, Kiko. 2011. "Carmencita on the road: Baile español y vaudeville en los Estados Unidos de América (1889-1895)", Revista Lumière. Disponible en: <http://www.elumiere.net/exclusivo_web/ carmencita/carmencita_on_the_road.php>. Fecha de acceso: 02 abr. 2014.

Mora, Kiko. 2014. "Carmen Dauset Moreno, primera musa del cine estadounidense". ZER Revista de Estudios de Comunicación 36: 13-35. Disponible en: <http://www.ehu.eus/zer/es/hemeroteca/ articulo/carmen-dauset-moreno-primera-musa-del-cine-estadounidense/550>. Fecha de acceso: 16 dic. 2014.

Mora, Kiko. 2016. "¡Y dale con Otero!... Flamencos en la Exposición Universal de París de 1900". Cadáver paraíso. Del espectáculo popular en la modernidad. Disponible en: <https:// cadaverparaiso.wordpress.com/2016/06/03/y-dale-con-otero-flamencos-en-la-exposicion-universalde-paris-de-1900/\#more-5>. Fecha de acceso: 4 jun. 2016.

Musser, Charles. 1997. Edison Motion Pictures, 1890-1900: An Annotated Filmography. Gemona: Le Giornate del Cinema Muto.

Navarrete Cardero, José L. 2009. Historia de un género cinematográfico: La Españolada. Madrid: Quiasmo.

Nayar, Sheila J. 2009. "Seeing voices: Oral pragmatics and the silent cinema". Early Popular Visual Culture 7(2): 145-165.

Nichols, Bill. 2001. "Los documentales y el Modernismo: 1919-1939". Comunicación y Sociedad 14(2): 71-91.

"Pan-American Exposition, Buffalo. May 1st to, November 1st, 1901". 1901. TLC, T 485 D 9 P 28. Disponible en: <https://archive.org/details/panamericanexpos03pana>. Acceso: 4 feb. 2016.

Plaza Orellana, Rocío. 2005. Bailes de Andalucía en Londres y París (1830-1850). Madrid: Arambel Editores.

Ramos Gay, Ignacio. 2006. "La imagen de España en los vaudevilles de Eugène Labiche y Georges Feydeau", en Bruña et al. (eds.), La cultura del otro: español en Francia, Francés en España: 650-657. Sevilla: Universidad de Sevilla.

"Résume de la semaine". L’Express de Lyon Illustré, 17 juin 1900.

Rey, Antonia del. 2013. "Segundo de Chomón, un guía turístico de cine". Revista científica de cine y fotografía 7: 5-22.

Rigney, Ann. 2007. "Representation", en Beller y Leerssen, op. cit: 415-418.

Rony, Fatimah T. 1996. The Third Eye. Race, cinema and ethnographic spectacle. Durham: Duke UP.

Said, Edward. 1978. Orientalism. Londres: Penguin.

Sazatornil, Luis y Ana Belén Lasheras. 2005. "París y la españolada. Casticismo y estereotipos nacionales en las exposiciones universales (1855-1900)". Mélanges de la Casa de Velázquez 35(2). Disponible en: <https://mcv.revues.org/2245>. Fecha de acceso: 23 jun. 2014.

Seguin, Jean-Claude. 1995. Historia del cine español. Madrid: Acento.

Sentlaurens, Jean. 2002. "Carmen: de la novela de 1845 a la zarzuela de 1887. Cómo nació "la España de Mérimée". Bulletin Hispanique 104.2: 851-872.

Steingress, Gerhard. 1993. Sociología del Cante Flamenco. Jerez: Fundación Andaluza de Flamenco. Torres, Augusto M. (ed.). 1989: Cine español. 1896-1988. Madrid: Ministerio de Cultura.

Vera Balanza, M. ${ }^{a}$ Teresa y Natalia Meléndez Malavé. 2008. "El mito de Carmen: exotismo, romanticismo e identidad". Ámbitos 17: 343-354.

Fecha de recepción: 13 de enero de 2016.

Fecha de aprobación: 20 de mayo de 2016. 